\title{
Does conformity occur during students' decision making for their careers?
}

\author{
Putri Fathia Fadilla ${ }^{*}$, Sri Muliati Abdullah ${ }^{2}$, Mingchang $\mathbf{W u}^{3}$ \\ ${ }^{1,2}$ Magister Psychology, University of Mercu Buana Yogyakarta, Indonesia \\ ${ }^{3}$ School of Humanity and Applied Science, National Yunlin \\ University of Science and Technology, Taiwan, ROC \\ *Corresponding author: putriff@yahoo.co.uk
}

Received: 5 February 2020; Accepted: 23 March 2020; Published: 26 March 2020

To cite this article (APA): Fadilla, P. F., Abdullah, S. M., \& Wu, M. (2020). Does conformity occur during students' decision making for their careers?. Asian Journal of Assessment in Teaching and Learning, 10(1), 1-9. https://doi.org/10.37134/ajatel.vol10.1.1.2020

To link to this article: https://doi.org/10.37134/ajatel.vol10.1.1.2020

\begin{abstract}
Students between ages 13 to 18 years old are exposed to have career development assignments of life focused on the education field such as choosing majors or career fields. Students see career decision making is always accompanied by feelings of doubt, uncertainty, and even stress. In the end, students make their choice on careers by just following the decisions of their peers, which is not necessarily the right decision for them. Their decision taken can lead to career success. The purpose of this study to determine the effect of the conformity of students' decision making for their careers. The quantitative research methods are used where the samples are 136 students of class XII. Data are obtained from the Likert scale instrument and analyzed using regression analysis. The result shows there is influence between conformity and students' decision making for their career. The findings of the research are the categorization score of conformity is in high category with $60.29 \%$, while the variable of career decision making is in the low category with $54.41 \%$. Thus, the coefficient value is $-0.573(\mathrm{p}<0.01)$ with an effective contribution of $32.9 \%$ and the remaining is $67.1 \%$ is determined by other variables, which are not considered in this research. This shows that the higher of conformity, so the lower of career decision making in the class XII students. Hence, this study is essential to provide a view on the importance of career decision making abilities that will affect the students' future.
\end{abstract}

Keywords: Conformity, Students, Career Decision Making

\section{INTRODUCTION}

Field of education is a very important field for improving the quality of human resources in order to be able to move in all aspects of life. Education is a benchmark for future career success, which needs to be fought for and ready for challenges and obstacles (Castro, Andres, \& Prestoza, 2018). Students are the next generation who are expected to be agents of change, which is why quality of education is very important (Martin, 2019). The term 'career' in the world of education is something that cannot be missed. Literally, the word 'career' means progress in life, but unfortunately it is understood only as a matter related to work. It turns out that career is dynamic and open throughout life as individual development in life includes work, education, training, community activities or activities after retirement (Craighead \& Nemeroff, 2004). It can be said that education is one part of a career.

The concept of life stages according to Super (2008) describes that at each stage of human development, there are tasks that must be fulfilled e.g. ages 15-24 years is the stage of individual development at the level of exploration. At this point, the task of career development is in understanding interests, abilities and pursuing career goals, more specifically in the career selection. According to Bowler \& Weinraub (2018), adolescents with age 13-18 years have the task of career development in the direction of life whose attention is focused on education such as choosing majors or career fields. It 
is hoped that each individual can complete each of them developmental tasks. Students who are in their teens often look at career exploration and decision making accompanied by feelings of doubt, uncertainty and even stress (Santrock, 2016). Students do not easily complete their career development tasks, such as having confusion in choosing study programs or setting goals, do not understand their talents or interests and feel anxious to get a job after graduating (Wahyuni, Nurdin, \& Nurbaity, 2018). In addition, the phenomenon that often arises until now is in determining their career choice, high school students still often follow the decisions of their friends which are not necessarily the right decision.

Putri (2018) conducted a two-year study to explore more than 400000 student profiles and data throughout Indonesia. From the survey results of this research, an interesting fact is found that $92 \%$ of high school/vocational students are confused and do not know what they will be in the future. Furthermore, $45 \%$ of the students feel that they have chosen a wrong major. One of the majors can have an impact on the desire to change majors. One of the factors that plays an important role in the decision of students to move to college is a mistake in career decision making (Fahima \& Akmal, 2018).

Career success in the future can be marked by career decisions taken. The suitability of career decisions made based on their abilities will make it easier for students to achieve success in the future, while the mismatch of career decision making can prevent students from achieving success in the future because with their abilities, students can measure the extent of confidence in making decisions (Setiobudi, 2017). The results showed consistently that students who already have future career choices have a better quality of life than those who have not decided on their career choices (Dewi, 2017). In accordance to Government Regulation (PP) No. 17 of 2010 article 76 paragraph 1, the function and purpose of high school is to increase physical and mental readiness and continue education to a higher level.

According to Krumboltz (2009), one of the factors in career decision making is environmental conditions, which include family, social influence of government policies, education systems, technological development, employment opportunities. Conformity is included in the factor of social influence where the notion of conformity is a social influence where individuals change their attitudes and behaviour to conform to existing social norms (Baron \& Byrne, 2005). Supported by Santrock (2011), the role of socially influential persons is important in decision making for students who are in their teens.

Based on this background, the formulation of the problem in this study is conformity influences student career decision making.

\section{CAREER DECISION MAKING}

The definition of career decision making according to Lee, Rojewski \& Hill (2013) is a process that includes the selection available to determine education or work that is in accordance with interests, personality types, feelings of opposition, opportunities and vocational identity they have. Decision making is useful for selecting from among choices or for the approval of opportunities (Sternberg, 2008). According to Betz (2007), aspect of career decision making consists of:

1. Self-appraisal

Self-appraisal is an individual's assessment of himself related to the abilities, talents, interests and situations of individuals. In this case, increasing the number of individuals who are able to do an assessment of themselves, for example students who are able to get the advantages and disadvantages that exist in themselves.

\section{Gathering occupational information}

Information on alternative job openings (majoring in college or employment), such as gathering a lot of information related to campus or areas of interest, what things need to be prepared and how to develop it if you will choose that career field. 
3. Goal selection

In this aspect, it needs to be improved where each individual is able to do his ability with the characteristics of various fields that exist. By knowing the various values of strengths and weaknesses that exist, students will find it easier to think of the potential that exists in itself to adjust to a particular field.

\section{The Factors of Career Decision Making}

General Model of Factors Affecting Occupational Selection (Krumboltz, 2009) describes the factors that influence a person in career decision making, as follows:

1. Genetic Influences

This factor is innate, such as race, gender or physical condition. Certain individuals are born with the ability to benefit from their experience with the environment, according to their special abilities such as intelligence, talent, to brain function. The results of Bouchard's research report show that vocational interest has a substantial genetic basis.

\section{Environmental Conditions}

Environmental factors affect career making, which include family, social influence, government policy, education system, technological development and employment opportunities. Based on Social Cognitive Theory, conformity is an external factor that comes from environmental influences (Fadilla \& Abdullah, 2019)

\section{Learning Experiences}

The most human activity is learning. Learning experience is an influence on the ability of individuals in career decisions because during the individual learning process, the nature of the results of the stimulus and reinforcement that has been passed will be formed.

\section{Task Approach Skill}

The ability factor in dealing with tasks is the result of interaction between genetic and the environment including skills such as problem solving, perception processes, cognitive processes and emotional responses.

\section{CONFORMITY}

Conformity is the adjustment of behaviour or thought to conform group standards (Myers, 2013). Conformity, according to Jiang, Bong \& Kim (2015), is the act of equating one's attitudes and behaviour with the majority (group) behaviour, eventhough the majority's response is contrary to personal beliefs. Conformity also means doing the same thing with others in accordance with norms, tastes, opinions, structuring and so forth that are behavioural in a group in which a person assumes himself as a member of the group (Richards, 2010). Opinions of (Sears, Freedman, \& Peplau, 2005) aspects of conformity consist of:

\section{Compactness}

Cohesiveness is the overall strength that causes a person to be attracted to a group and makes them want to remain a member. The greater the likes of one member towards other members, and the greater the expectation to benefit from group membership and the greater their loyalty, 
the more compact the group will be. The close relationship between the individual and the group is caused by feelings of like between group members and the hope of benefiting from their membership.

\section{Agreement}

Trust in groups and equality of opinion among group members due to individual dependence on groups. The opinions of the reference groups that have been made have strong pressure so that individuals must be loyal and adjust their opinions to those of the group. Individuals who are faced with group decisions that are unanimous will be under strong pressure to adjust their opinions to those of the group. If the groups are not united, there will be a decrease in the level of conformity. Decreased conformity due to lack of agreement can be caused by several factors including:

a) The level of trust in the majority will decrease if there is a difference of opinion.

b) If the individual has a different opinion from the group then the individual will be ostracized and deviated.

c) If the group has the same opinion as the individual's opinion, the individual's belief in their own opinion will be stronger.

3. Obedience

Obedience is a willingness to take action and obey the rules of the group even though the individual does not want to do it because of pressure from group members and wants to meet group expectations. Pressure due to reward, punishment or threat is one way to cause obedience.

\section{METHODOLOGY}

This research method is quantitative with career decision making as dependent variable and conformity as independent variable. The sampling technique used in this research is cluster random sampling with a sample of 136 students. Data are obtained through a scale instrument with a Likert scale type consisting of favorable and unfavorable statements and are analyzed using regression analysis. The explanation of this research instrument is as follows:

Table 1. Blueprint Career Decision Making Scale Before Try Out

\begin{tabular}{|c|l|c|c|c|}
\hline \multirow{2}{*}{ No } & \multicolumn{1}{|c|}{ Aspect } & \multicolumn{2}{|c|}{ Statement } & \multirow{2}{*}{ Total } \\
\cline { 3 - 5 } & & Favourable & Unfavourable & \multirow{2}{*}{8} \\
\hline 1 & Self-appraisal & $1,2,3,4$ & $5,6,7,8$ & 8 \\
\hline 2 & Gathering occupational information & $9,10,11,12$ & $13,14,15,16$ & 8 \\
\hline 3 & Goal selection & $17,18,19,20$ & $21,22,23,24$ & 24 \\
\hline
\end{tabular}

Validity test is done by using the Pearson Correlation ( $\mathrm{r}$ count) value rule which is greater than $\mathrm{r}$ table. The power difference obtained with a significance level of 0.01 is 0.442 . All items that reached a correlation coefficient $\geq 0.442$ differed in terms of their psychometric qualifications as part of the test. After testing the validity of 24 items, there were 21 items that were declared as valid items, while 3 items had a correlation coefficient $<0.442$ declared null. Valid items begin with the lowest correlation value of 0.467 in item number 16 and the highest correlation value of 0.854 in item number 1 . A total of 3 items are declared null, namely items number 5, 14 and 19. Career decision scale has a Cronbach's Alpha value of 0.948. Blue print after testing the scale of career decision making can be seen in Table 2. 
Table 2. Blueprint Career Decision Making Scale After Try Out

\begin{tabular}{|c|c|c|c|c|}
\hline \multirow{2}{*}{ No } & \multirow{2}{*}{ Aspect } & \multicolumn{2}{|c|}{ Statement } & \multirow{2}{*}{ Total } \\
\cline { 2 - 5 } & Self-appraisal & Favourable & Unfavourable & 7 \\
\hline 1 & Gathering information & $1,2,3,4$ & $5,6,7$ & 7 \\
\hline 3 & Goal selection & $15,9,10,11$ & $12,13,14$ & 7 \\
\hline & Total & 11 & $18,19,20,21$ & 21 \\
\hline
\end{tabular}

Table 3. Blueprint Conformity Scale Before Try Out

\begin{tabular}{|c|c|c|c|c|}
\hline \multirow{2}{*}{ No } & \multirow{2}{*}{ Aspect } & \multicolumn{2}{|c|}{ Statement } & \multirow{2}{*}{ Total } \\
\cline { 3 - 5 } & & Favourable & Unfavourable & 8 \\
\hline 1 & Compactness & $1,2,3,4$ & $5,6,7,8$ & 8 \\
\hline 2 & Agreement & $9,10,11,12$ & $13,14,15,16$ & 8 \\
\hline 3 & Obedience & $17,18,19,20$ & $21,22,23,24$ & 24 \\
\hline & Total & 12 & 12 & 8 \\
\hline
\end{tabular}

After testing the validity of 24 items, 22 items were declared as valid items, while 2 items were considered null. Valid items begin with the lowest correlation value of 0.485 in item number 7 and the highest correlation value of 0.820 in item number 11 . A total of 2 items with a correlation of $<0.4442$ are declared invalid items number 3 and 16. Conformity scale has a Cronbach's Alpha value of 0.946. Blue Print after testing the scale of conformity can be seen in Table 4.

Table 4. Blueprint Conformity Scale After Try Out

\begin{tabular}{|c|c|c|c|c|}
\hline \multirow{2}{*}{ No } & \multirow{2}{*}{ Aspect } & Favourable & Statement & \multirow{2}{*}{ Total } \\
\cline { 2 - 5 } & & $1,2,3$ & $4,5,6,7$ & 7 \\
\hline 1 & Compactness & $8,9,10,11$ & $12,13,14$ & 7 \\
\hline 2 & Agreement & $15,16,17,18$ & $19,20,21,22$ & 8 \\
\hline 3 & Obedience & 11 & 11 & 22 \\
\hline
\end{tabular}

\section{RESULT AND DISCUSSION}

\section{Data Description}

Data obtained from questionnaire answers on career decision making scales, conformity scales and selfefficacy scales are used as a reference in describing research results by comparing hypothetical scores with empirical scores. Descriptive analysis was carried out to determine the minimum value, maximum, distance distribution (range), standard deviation and average (mean). These results are then used as a basis for categorizing research data. Hypothetical and empirical score calculation results can be seen in Table 5.

Table 5. Hypothetic and Empirical Data

\begin{tabular}{|c|c|c|c|c|c|c|c|c|}
\hline \multirow{2}{*}{ Variable } & \multicolumn{4}{|c|}{ Hypothetic Data } & \multicolumn{4}{c|}{ Empirical Data } \\
\cline { 2 - 9 } & Min & Max & Mean & SD & Min & Max & Mean & SD \\
\hline Career Decision Making & 21 & 84 & 52.5 & 10.5 & 27 & 84 & 55.5 & 9.5 \\
\hline Conformity & 22 & 88 & 55 & 11 & 26 & 85 & 55.5 & 9.833 \\
\hline
\end{tabular}


The researcher also categorizes the data on the scale of career decision making and conformity based on the assessment of individuals in the group which is an estimate of the individual's score in contributions (Azwar, 2019). The results of the categorization are displayed in

Figure 1.

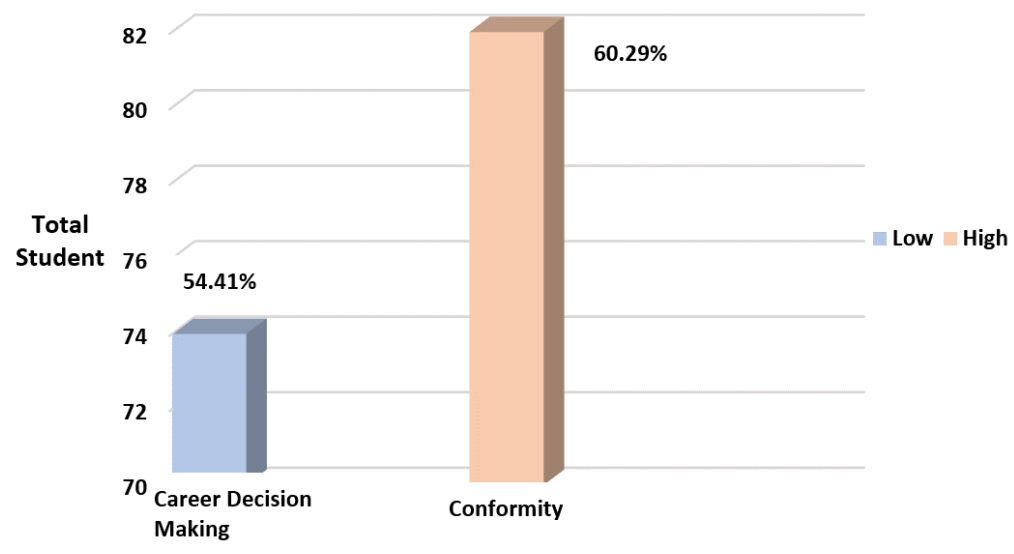

Figure 1. Categorization of Research Variables

Before analyzing the data in the hypothesis test, it is necessary to test the assumptions which consist of a normality test and a linearity test. The results of the assumptions of research data are as follows:

\section{Normality}

Normality test is used to determine whether the sample data taken is from a normally distributed population or not (Azwar, 2018). If the test is normal, the statistical calculation results can be generalized to the population. The normality test used in this study uses the Kolmogorof-Smirnov test, with the data rule stated to be normally distributed if $p>0.01$. The results of the normality test are as shown in Table 6.

Table 6. Result of Normality Test

\begin{tabular}{|c|c|c|c|c|}
\hline Variable & Kolmogorv Smirnov Z & p & Subject & Meaning \\
\hline Career Decision Making & 0.738 & 0.684 & 136 & Normal \\
\hline Conformity & 0.307 & 0.967 & 136 & Normal \\
\hline
\end{tabular}

\section{Linearity}

The linearity assumption states that for each linear regression equation, the relationship between the independent variable and the dependent variable must be linear (Azwar, 2018). The based is used to determine the linearity of the research variable if $\mathrm{p}<0.01$ then it is said that the variable has a linear relationship. Linearity test results can be seen in Table 7.

Table 7. Result of Linearity Test

\begin{tabular}{|c|c|c|c|}
\hline \multirow{2}{*}{ Variable } & \multicolumn{2}{|c|}{ Value } & \multirow{2}{*}{ Meaning } \\
\cline { 2 - 3 } & $\mathbf{F}$ & $\mathbf{p}$ & \\
\hline Conformity $\rightarrow$ Career Decision Making & 1.028 & 0.447 & Linear \\
\hline
\end{tabular}

\section{Hypothesis}


Hypothesis testing used regression analysis to determine the effect of conformity to career decision making, the results in Table 8 are obtained.

Table 8. Result of Regression Analysis

\begin{tabular}{|c|c|c|c|}
\hline \multirow{2}{*}{ Variable } & \multicolumn{2}{|c|}{ Value } & \multirow{2}{*}{ Meaning } \\
\cline { 2 - 3 } & Coefficient & p & \\
\hline Conformity $\rightarrow$ Career Decision Making & $-0,573$ & 0.000 & Significant \\
\hline
\end{tabular}

Based on the results of hypothesis testing above, the effect of conformity variables on career decision making on students obtained a correlation coefficient of -0.573 with a significance of $0.000(\mathrm{p}<0.01)$, this means the hypothesis is accepted.

Conformity is an individual action to equate oneself both in behaviour, belief or thought in accordance with the group. Human behaviour is a component of a model that interacts with each other between the components of the environment, as well as human personal components which include the affection and cognitive of individuals (Abdullah, 2019). Conformity as a factor of the environment influences career decision making can be described in the dynamics relationship in every aspect of conformity.

The first aspect of conformity is cohesiveness, in this aspect found the subject's response shows that in determining career choices students tend to equate with the choices of their peers. This finding is in accordance with the opinion of Kundu \& Cummins (2012) that cohesiveness can affect individual decisions, because individuals will feel a dilemma when they hear that most people give different decisions. Individuals will try to change their decisions to be the same as those of most people. Cohesiveness that occurs in students can be caused because students find it difficult to know the ability of this self is seen in the self-appraisal aspects of career decision making, so students decide to make the same choices as their peers. Because the more ambiguous or more difficult a task is, individuals tend to adjust to group assessments (Taylor, Peplau, \& David, 2009). Conformity of students as adolescents can occur because their tendency to achieve integration of social relationships as characteristic of adolescent development (Fillamenta, 2018).

The second aspect of conformity is agreement, based on data found in deciding career choices students believe in decisions in groups. Trust in groups and equality of opinion among group members due to individual dependence on groups, the greater the students' trust in group information and opinions, the more likely students are to adjust to the group. According to the results of research conducted by Lahno \& Garcia (2015) entitled "Peer Effect in Risk Taking: Envy or Conformity?", conformity behaviour done by adolescents based on peer preference is a dependency caused by agreement. Individuals like the group so that the group will be easy to change individual behaviour this is called ingratiation which is the basic principle of agreement based on liking/friendship. When making career decisions based on agreement, students want to be considered right by thinking and acting like a group. According to Baron \& Byrne (2005), conformity is done by someone with the aim of obtaining social validation.

The third aspect of conformity is obedience, which is defined as willingness to take action and obey group rules because individuals try to always be socially acceptable and avoid rejection. This is in accordance with the students' responses in determining the career choices of students following the provisions in the group so that they are not isolated. Age of class XII students belongs to the category of adolescents, hence, social acceptance is very important for them because if teenagers do not have a friendship environment then the teenager feels like nobody (Boeree, 2013). In determining career choices, students are suspected to be more likely to follow group decisions in order to gain social acceptance because peer groups play a major role in meeting the needs of adolescents socially and emotionally. Individuals who identify themselves with groups cause the individual's dependence on their parents to decline (Padmomartono, 2014).

Based on the description above, it can be concluded that the results in this study prove that there is an influence between conformity on career decision making in class XII students. The effective contribution $\left(\mathrm{R}^{2}\right)$ of the conformity variable to career decision making is $32.9 \%$. This is also in 
accordance with the results of the categorization of conformity included in the high category $(60.29 \%)$ while the career decision making category is lacking (54.41\%). This finding is supported by the opinion of Cialdini \& Goldstein (2004) which states that most students in considering majors, courses / training choices and determining careers are based on peer conformity as social influences. The acceptance of the first hypothesis in this study can strengthen the results of Vatmawati's research (2019) which shows that the relationship of student conformity with career decision making $\left(\mathrm{r}_{\mathrm{xy}}\right)$ of 0.465 is quite a strong category.

\section{CONCLUSION}

Based on the results of this study concluded that there is a direct effect between conformity on career decision making in class XII students. This study proved that categorization score of conformity is high, while the variable of career decision making is in the low category. That means the higher of conformity, so the lower of career decision making in the class XII students. It is hoped that the next researcher will be able to examine the effective contribution of other variables that not yet examined in this study such as family social support, the role of the counseling guidance and career planning.

\section{REFERENCES}

Abdullah, S. M. (2019). Social cognitive theory: a Bandura thought review published in 1982-2012. Psikodimensia, 18(1), 85-100. https://doi.org/10.24167/psidim.v18i1.1708

Azwar, S. (2018). Metode penelitian psikologi edisi II. Yogyakarta: Pustaka Pelajar.

Azwar, S. (2019). Penyusunan skala psikologi edisi II. Yogyakarta: Pustaka Pelajar.

Baron, \& Byrne. (2005). Psikologi sosial edisi kesepuluh. Jakarta: Erlangga.

Betz, N. E. (2007). Career Self-Efficacy: Exemplary recent research and emerging directions. Journal of Career Assessment, 15(4), 403-422.https://doi.org/10.1177/1069072707305759

Boeree, G. (2013). General psychology. Yogyakarta: Prismashopie.

Bowler, G., \& Weinraub, M. (2018). The SAGE encyclopedia of lifespan human development. https://doi.org/10.4135/9781506307633

Castro, M. R. D., Andres, P. D., \& Prestoza, M. J. R. (2018). The Teaching Techniques and Strategies Use by the Dressmaking Teachers Perceive by the Dressmaking Students. Asian Journal of Assessment in Teaching and Learning, 8, 48-56. Retrieved http://ejournal.upsi.edu.my/index.php/AJATeL/article/view/1988

Cialdini, R. B., \& Goldstein, N. J. (2004). Social influence: compliance and conformity. Annual Review of Psychology, 55(1), 591-621. https://doi.org/10.1146/annurev.psych.55.090902.142015

Craighead, E. W., \& Nemeroff, C. B. (2004). The concise corsini encyclopedia of psychology and behavioral science (3rd ed.). Canada: John Wiley \& Sons, Inc.

Dewi, R. P. (2017). Hubungan efikasi diri dengan pengambilan keputusan karir pada mahasiswa tingkat akhir fakultas psikologi Univeritas Mercu Buana Yogyakarta. Insight, 19(2), 87-99.

Fadilla, P. F., \& Abdullah, S. M. (2019). Faktor pengambilan keputusan karier pada siswa SMA ditinjau dari Social Cognitive Theory. Jurnal Psikostudia, 8(2), 108-115.

Fahima, R. R., \& Akmal, S. Z. (2018). Peranan kebimbangan karier terhadap intensi pindah jurusan kuliah pada mahasiswa. Psympathic : Jurnal Ilmiah Psikologi, 5(1), 83-94. https://doi.org/10.15575/psy.v5i1.1639

Fillamenta, N. (2018). Teenagers self-identity who experience internet addiction. Asian Journal of Assessment in Teaching and Learning, 8, 1-6. Retrieved from http://ejournal.upsi.edu.my/index.php/AJATeL/article/view/1984

Jiang, Y., Bong, M., \& Kim, S. il. (2015). Conformity of Korean adolescents in their perceptions of social relationships and academic motivation. Learning and Individual Differences, 40, 41-54. https://doi.org/10.1016/j.lindif.2015.04.012

Krumboltz, J. D. (2009). The happenstance learning theory. Journal of Career Assessment, 17(2), $135-154$. https://doi.org/10.1177/1069072708328861

Kundu, P., \& Cummins, D. D. (2012). Morality and conformity: the Asch paradigm applied to moral decisions. Social Influence, 8(4), 268-279. https://doi.org/10.1080/15534510.2012.727767

Lahno, A. M., \& Garcia, M. S. (2015). Peer effects in risk taking: Envy or conformity? Journal of Risk and Uncertainty, 50(1), 73-95. https://doi.org/10.1007/s11166-015-9209-4 
Lee, I. H., Rojewski, J. W., \& Hill, R. B. (2013). Classifying Korean adolescents' career preparedness. International Journal for Educational and Vocational Guidance, 13(1), 25-45. https://doi.org/10.1007/s10775-012-9236-5

Martin, M. (2019). Implementation and usefulness of outcomes-based instruction among college of education students. Asian Journal of Assessment in Teaching and Learning, 9(2), 18-28. Retrieved from http://ejournal.upsi.edu.my/index.php/AJATeL/article/view/2790

Myers, D. G. (2013). Psychology tenth edition. New York: Worth Publisher.

Padmomartono, S. (2014). Konseling remaja. Yogyakarta: Ombak.

Putri, N. (2018). Angka siswa yang salah pilih jurusan masih tinggi. Retrieved September 10, 2019, from http://www.skystarventures.com/youthmanual-angka-siswa-yang-salah-pilih-jurusan-masih-tinggi/

Richards, G. (2010). Serial konsep-konsep kunci psikologi. Yogyakarta: Pustaka Baca.

Santrock, J. W. (2011). Educational psychology fifth edition (Vol. 111). https://doi.org/10.1192/bjp.111.479.1009-a

Santrock, J. W. (2016). Adolescence 16th Edition. New York: McGraw-Hill Education.

Sears, O. D., Freedman, J. L., \& Peplau, L. A. (2005). Psikologi sosial (terjemahan Michael Adryanto). Jakarta: Erlangga.

Setiobudi, J. (2017). Pengaruh efikasi diri terhadap pengambilan keputusan karir pada siswa kelas XII SMA Negeri 1 Kalasan. E-Journal Bimbingan Dan Konseling, 1.

Sternberg, R. J. (2008). Psikologi kognitif edisi keempat. Yogyakarta: Pustaka Pelajar.

Super, D. (2008). The big five career theories: self-concept theory of career development (in international handbook of career guidance). Jerman: Springer Science Business Media.

Taylor, S. E., Peplau, L. A., \& David, O. S. (2009). Psikologi sosial edisi kedua belas. Jakarta: Kencana Prenada Media Group.

Vatmawati, S. (2019). Hubungan konformitas siswa dengan pengambilan keputusan karir. Jurnal Bimbingan Dan Konseling Empati, 6(1), 55-70.

Wahyuni, C. L., Nurdin, S., \& Nurbaity. (2018). Kematangan karir siswa SMA Negeri I Bandar Dua Pide Jaya. Jurnal Ilmiah Mahasiswa Bimbingan Dan Konseling, 3(4), 10-18. 